\title{
Microcella alkaliphila sp. nov., a novel member of the family Microbacteriaceae isolated from a non- saline alkaline groundwater, and emended description of the genus Microcella
}

\author{
Igor Tiago, ${ }^{1,2}$ Paula V. Morais, ${ }^{3,4}$ Milton S. da Costa ${ }^{2,3}$ \\ and António Veríssimo ${ }^{1,2}$
}

Correspondence

António Veríssimo

averiss@ci.uc.pt

\begin{abstract}
Departamento de Zoologia ${ }^{1}$, Centro de Neurociências de Biologia Celular², Departamento de Bioquímica ${ }^{3}$ and Instituto do Ambiente e Vida ${ }^{4}$, Universidade de Coimbra, 3004-517 Coimbra, Portugal
\end{abstract}

\begin{abstract}
A high-G + C-content Gram-positive bacterium, designated as strain $\mathrm{AC} 4 \mathrm{r}^{\top}$, was isolated from a highly alkaline, non-saline groundwater environment $(\mathrm{pH} \mathrm{11 \cdot 4).} \mathrm{This} \mathrm{organism} \mathrm{formed} \mathrm{small}$ rod-shaped cells, was aerobic, heterotrophic, catalase-positive and oxidase-negative and had an optimum growth temperature of $35^{\circ} \mathrm{C}$ and an optimum $\mathrm{pH}$ of $9 \cdot 5$. The strain possessed a $\mathrm{B} 2 \beta$-type cell-wall peptidoglycan, with D-Orn as the diagnostic diamino acid. The major respiratory quinones were unsaturated menaquinones with 13 and 14 isoprene units. The predominant fatty acids were anteiso-15:0, iso-16:0, iso-14:0 and iso-15:0. The $G+C$ content of the DNA was $67 \cdot 1 \mathrm{~mol} \%$. In a $16 \mathrm{~S}$ rRNA gene sequence analysis, strain $A C 4 r^{\top}$ showed the highest level of similarity $(99 \cdot 2 \%)$ to the type strain of Microcella putealis; however, the DNA-DNA reassociation value between these two organisms was low (38.3\%). On the basis of phylogenetic analysis, the DNA-DNA reassociation value and distinct phenotypic characteristics, strain $A C 4 r^{\top}$ represents a novel species within the genus Microcella, for which the name Microcella alkaliphila sp. nov. is

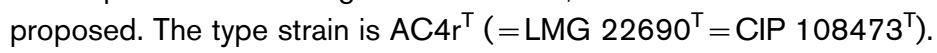

The ophiolite-like geological context of the aquifer at Cabeço de Vide in southern Portugal, together with its chemical characteristics, strongly suggests serpentinization activity. The groundwater vents at a temperature of $20.5^{\circ} \mathrm{C}$ and has high alkalinity ( $\mathrm{pH} \mathrm{11.4)}$ associated with an extremely low ionic concentration, with $\mathrm{Ca}^{2+}$ and $\mathrm{OH}^{-}$as major chemical constituents (Tiago et al., 2004). The majority of the bacterial isolates recovered from Cabeço de Vide groundwater belonged to the recently described species Microcella putealis (Tiago et al., 2005). In this study, we report the taxonomic characterization of another Cabeço de Vide isolate that represents a novel species of the genus Microcella.

Strain $\mathrm{AC} 4 \mathrm{r}^{\mathrm{T}}$ was isolated from borehole water at Cabeço de Vide on alkaline buffered medium 2 (ABM2), adjusted to $\mathrm{pH} 9 \cdot 5$, at $30{ }^{\circ} \mathrm{C}$, as described previously (Tiago et al., 2004). The isolate was routinely cultured under the same conditions and maintained at $-70{ }^{\circ} \mathrm{C}$ in the same

The GenBank/EMBL/DDBJ accession number for the 16S rRNA gene sequence of strain $A C 4 r^{\top}$ is $A J 717385$.

The fatty acid compositions of strain $\mathrm{AC} \mathrm{r}^{\top}$ and Microcella putealis $\mathrm{CV} 2^{\top}$ and a phylogenetic dendrogram are available as supplementary material in IJSEM Online. medium supplemented with $15 \%$ glycerol. Unless otherwise stated, all morphological, biochemical and tolerance tests were performed on that medium at $35^{\circ} \mathrm{C}$, with incubation for up to 6 days as described previously (Tiago et al., 2005).

The growth-temperature range of strain $\mathrm{AC}^{\mathrm{T}} \mathrm{r}^{\mathrm{T}}$ was examined in ABM2 liquid medium buffered at $\mathrm{pH} 9 \cdot 5$; the $\mathrm{pH}$ range for growth was determined at $35^{\circ} \mathrm{C}$ in the same medium, and growth in the presence of $\mathrm{NaCl}$ was examined in liquid medium at $\mathrm{pH} 9.5$ and $35^{\circ} \mathrm{C}$ as described previously (Tiago et al., 2005).

Assimilation of single carbon sources was determined using API $50 \mathrm{CH}$ test strips (bioMérieux), with $0 \cdot 1 \mathrm{M}$ carbonate/ bicarbonate buffer $(\mathrm{pH} 9 \cdot 5)$ supplemented with $0.3 \%(\mathrm{w} / \mathrm{v})$ agar (Difco), $0.05 \% \mathrm{NH}_{4} \mathrm{Cl}$ (Merck) and macronutrient and micronutrient solutions as described previously (Tiago et al., 2005). Anaerobic growth was assessed at $35^{\circ} \mathrm{C}$ in anaerobic chambers with a $\mathrm{H}_{2} / \mathrm{CO}_{2}$ atmosphere (bioMérieux).

Strain AC4r ${ }^{\mathrm{T}}$ formed yellow-pigmented colonies and Grampositive, small, rod-shaped, non-motile cells $(0 \cdot 3 \mu \mathrm{m}$ in width and 3-4 $\mu \mathrm{m}$ in length). The isolate had an optimum growth temperature of $35^{\circ} \mathrm{C}$ and did not grow at 20 or $45^{\circ} \mathrm{C}$. 
The optimum $\mathrm{pH}$ for growth was $9 \cdot 5$; no growth was observed at $\mathrm{pH} 7 \cdot 5$ or $\mathrm{pH} 10 \cdot 5$. Optimal growth was observed in the absence of $\mathrm{NaCl}$, but growth occurred in ABM2 containing up to $8.0 \% \mathrm{NaCl}$. Despite having the same optimal temperature as the type strain of $M$. putealis, strain $\mathrm{AC} 4 \mathrm{r}^{\mathrm{T}}$ had a narrower temperature range for growth, a higher optimal $\mathrm{pH}$ for growth and did not grow below pH 8.0 (Tiago et al., 2005).

Strain $\mathrm{AC}^{\mathrm{T}} \mathrm{r}^{\mathrm{T}}$ and the type strain of $M$. putealis utilized several sugars and proteinaceous substrates, but several differences between the two strains were detected that can be used to distinguish the strains (Table 1).

Purified cell-wall preparations were obtained by using the method of Schleifer \& Kandler (1972). The amino acids and peptides in cell-wall hydrolysates were analysed as described previously (Schleifer \& Kandler, 1972; Schleifer, 1985). Lipoquinones were extracted (from $300 \mathrm{mg}$ freeze-dried cells) and detected as described previously (Tindall, 1989). Cultures used for fatty acid analyses were grown on ABM2 medium, adjusted to $\mathrm{pH} \mathrm{9.5,} \mathrm{in} \mathrm{sealed} \mathrm{plastic} \mathrm{bags}$ submerged in a water bath at $35^{\circ} \mathrm{C}$ for $24 \mathrm{~h}$. Fatty acid methyl esters were obtained from fresh wet biomass by saponification, methylation and extraction as described previously and were separated, identified and quantified with standard MIS Library Generation Software as described by the manufacturer (Microbial ID).

The peptidoglycan of strain $\mathrm{AC} 4 \mathrm{r}^{\mathrm{T}}$ was of the $\mathrm{B} 2 \beta$ type (according to the nomenclature of Schleifer \& Kandler, 1972), with L-homoserine in position 3 of the tetrapeptide and an interpeptide bridge containing glycine and Dornithine. Although the peptidoglycan structure determined for the novel strain and for M. putealis $\mathrm{CV} 2^{\mathrm{T}}$ is of type $\mathrm{B}$, the diagnostic diamino acid of M. putealis strain $\mathrm{CV}^{\mathrm{T}}$ is Lys, although the complete peptidoglycan structure of $M$. putealis remains unknown (Tiago et al., 2005). The respiratory quinones found in strain $\mathrm{AC} 4 \mathrm{r}^{\mathrm{T}}$ were menaquinones: MK-13 (47\%), MK-14 (35\%) and MK-12 (18\%). The menaquinone composition and the relative amounts of the menaquinones constitute additional distinctive features of the novel isolate in comparison with the species $M$. putealis (Table 1). The fatty acid composition of strain $\mathrm{AC} 4 \mathrm{r}^{\mathrm{T}}$ was characterized by the predominance of branched fatty acids, namely anteiso-15:0, iso-16:0, iso-14:0 and iso- $15: 0$, which constituted $32 \cdot 6,30 \cdot 8,12 \cdot 5$ and $9 \cdot 8 \%$, respectively, of the total fatty acids. The fatty acid profiles of $\mathrm{AC} 4 \mathrm{r}^{\mathrm{T}}$ and of the type strain of M. putealis are similar (see Supplementary Table S1 available in IJSEM Online).

Table 1. Phenotypic characteristics that differentiate strain $A C 4 r^{\top}$ from $M$. putealis

Data for M. putealis are based on three strains and were taken from Tiago et al. (2005). Characteristics are scored as follows: + , positive; - , negative; $\mathrm{W}$, weak reaction; $\mathrm{v}$, variable among strains (reaction of type strain in parentheses).

\begin{tabular}{|c|c|c|}
\hline Characteristic & Strain $A C 4 r^{T}$ & M. putealis \\
\hline Cell size $(\mu \mathrm{m})$ & $0 \cdot 3 \times 3 \cdot 0-4 \cdot 0$ & $0 \cdot 4 \times 0 \cdot 8-1 \cdot 6$ \\
\hline Growth temperature range $\left({ }^{\circ} \mathrm{C}\right)$ & $25-40$ & $15-40$ \\
\hline Optimum pH & $9 \cdot 5$ & $8 \cdot 5-9 \cdot 0$ \\
\hline $\mathrm{pH}$ range & $8 \cdot 0-10 \cdot 0$ & $7 \cdot 5-10 \cdot 0$ \\
\hline Urease & + & $\mathrm{w}$ \\
\hline$\beta$-Galactosidase & + & - \\
\hline \multicolumn{3}{|l|}{ Degradation/hydrolysis of: } \\
\hline Casein & - & + \\
\hline Starch & $\mathrm{W}$ & + \\
\hline \multicolumn{3}{|l|}{ Utilization of sole carbon sources } \\
\hline D-Arabinose & + & - \\
\hline D-Mannose & - & + \\
\hline L-Rhamnose & + & - \\
\hline Inulin & - & $\mathrm{v}(+)$ \\
\hline Starch & - & + \\
\hline Glycogen & - & + \\
\hline Xylitol & - & + \\
\hline L-Fucose & + & - \\
\hline Gluconate & - & + \\
\hline 2-Ketogluconate & + & - \\
\hline 5-Ketogluconate & - & + \\
\hline Major menaquinones & MK-13, MK-14, MK-12 & MK-12, MK-13, MK-14, MK-11 \\
\hline Cell-wall diamino acid & D-Orn & Lys \\
\hline
\end{tabular}


DNA for determination of the $\mathrm{G}+\mathrm{C}$ content was isolated as described by Nielsen et al. (1995). The G $+\mathrm{C}$ content of the DNA was determined by HPLC as described by Mesbah et al. (1989). The DNA relatedness between the type strain of $M$. putealis and novel strain $\mathrm{AC}^{\mathrm{T}}{ }^{\mathrm{T}}$ was determined by DNADNA hybridization. For this purpose, DNA was isolated and purified as described by Cashion et al. (1977) and reassociation reactions were carried out as described by De Ley et al. (1970) with the modifications described by Huß et al. (1983).

The 16S rRNA gene was amplified and sequenced as described by Tiago et al. (2004) and phylogenetic analysis was performed using the software package MEGA3 (Kumar et al., 2004) after multiple alignments of the sequence data had been obtained using CLUSTAL_X (Thompson et al., 1997). Evolutionary distances were calculated by using the method of Jukes \& Cantor (1969), phylogenetic dendrograms were constructed using the neighbour-joining method (Saitou \& Nei, 1987) and tree topologies were evaluated by performing a bootstrap analysis (Felsenstein, 1985) of 1000 datasets.

The DNA G + C content determined for strain $A C 4 r^{T}$ was $67 \cdot 1 \mathrm{~mol} \%$. Comparative analyses of 1505 nucleotide positions of the 16S rRNA gene sequence of strain $\mathrm{AC} 4 \mathrm{r}^{\mathrm{T}}$ with respect to representatives of the main lines of descent within the domain Bacteria indicated that this strain is a member of the family Microbacteriaceae (see Supplementary Fig. S1 available in IJSEM Online). The most closely related organism was M. putealis $\mathrm{CV}^{\mathrm{T}}(99 \cdot 2 \%$ similarity). Despite the close phylogenetic relationship, the two strains exhibited a DNA-DNA reassociation value of only $38 \cdot 3 \%$. This fact, together with the distinctive phenotypic characteristics of strain $\mathrm{AC} 4 \mathrm{r}^{\mathrm{T}}$, clearly indicates that it represents a novel species of the genus Microcella, for which we propose the name Microcella alkaliphila sp. nov.

\section{Description of Microcella alkaliphila sp. nov.}

Microcella alkaliphila (al.ka.li' phi.la. N.L. n. alkali alkali; Gr. adj. philos loving; N.L. fem. adj. alkaliphila loving alkaline environments).

Cells are small, rod-shaped, $0 \cdot 3 \times 3 \cdot 0-4 \cdot 0 \mu \mathrm{m}$, non-motile and Gram-positive. Non-endospore-forming. Aerobic and heterotrophic. Colonies are small, smooth, convex and yellow. Oxidase-negative and catalase-positive. The optimum temperature for growth is about $35^{\circ} \mathrm{C}$; no growth occurs at 10 or $45^{\circ} \mathrm{C}$. The optimum $\mathrm{pH}$ is $9 \cdot 5$; no growth occurs at $\mathrm{pH} 7 \cdot 5$ or $10 \cdot 5$. Grows in medium containing up to $8.0 \% \mathrm{NaCl}$, but the growth rate is higher without added $\mathrm{NaCl}$. Peptidoglycan is type $\mathrm{B} 2 \beta$ with D-Orn as the diagnostic diamino acid. The major respiratory quinones are MK-13 and MK-14. The predominant fatty acids (i.e. constituting approx. $10 \%$ or more) are anteiso- $15: 0$, iso- $16: 0$, iso- $14: 0$ and iso-15:0. The type strain does not hydrolyse elastin, aesculin, gelatin, arbutin or casein. Hydrolyses starch and arginine. Urease, $\beta$-galactosidase and DNase are present; xylanase is not detected. Nitrate is not reduced. The type strain assimilates glycerol, arabinose, ribose, D-xylose, galactose, glucose, fructose, L-rhamnose, mannitol, cellobiose, maltose, sucrose, D-turanose and 2-ketogluconate. The DNA G + C content of the type strain is $67 \cdot 1 \mathrm{~mol} \%$.

The type strain, $\mathrm{AC}^{\mathrm{T}} \mathrm{r}^{\mathrm{T}}\left(=\mathrm{CIP} 108473^{\mathrm{T}}=\mathrm{LMG} 22690^{\mathrm{T}}\right)$, was isolated from water from the borehole at Cabeço de Vide in southern Portugal.

\section{Emended description of the genus Microcella Tiago et al. 2005}

The genus description is as given by Tiago et al. (2005), with the following modifications and additions. The cell-wall peptidoglycan is of the B-type, with Lys or Orn as the diamino acid. The major isoprenologues are unsaturated menaquinones with 12-14 isoprene units.

\section{Acknowledgements}

This research was funded, in part, by FCT/FEDER project POCTI/BSE/ 42732/2001. We thank Dr Peter Schumann (Deutsche Sammlung von Mikroorganismen und Zellkulturen GmbH, Braunschweig, Germany) for determining the peptidoglycan structure and Dr Fernanda Nobre (Universidade de Coimbra, Portugal) for helping with the fatty acid methyl ester analysis. We also thank the Junta de Freguesia de Cabeço de Vide and Mr Manuel Fontainhas for giving us permission to collect the water samples.

\section{References}

Cashion, P., Holder-Franklin, M. A., McCully, J. \& Franklin, M. (1977). A rapid method for the base ratio determination of bacterial DNA. Anal Biochem 81, 461-466.

De Ley, J., Cattoir, H. \& Reynaerts, A. (1970). The quantitative measurement of DNA hybridization from renaturation rates. Eur $J$ Biochem 12, 133-142.

Felsenstein, J. (1985). Confidence limits on phylogenies: an approach using the bootstrap. Evolution 39, 783-791.

Huß, V. A. R., Festl, H. \& Schleifer, K. H. (1983). Studies on the spectrometric determination of DNA hybridization from renaturation rates. Syst Appl Microbiol 4, 184-192.

Jukes, T. H. \& Cantor, C. R. (1969). Evolution of protein molecules. In Mammalian Protein Metabolism, pp. 21-132. Edited by H. N. Munro. New York: Academic Press.

Kumar, S., Tamura, K. \& Nei, M. (2004). MEGA3: integrated software for molecular evolutionary genetics analysis and sequence alignment. Brief Bioinform 5, 150-163.

Mesbah, M., Premachandran, U. \& Whitman, W. B. (1989). Precise measurement of the $\mathrm{G}+\mathrm{C}$ content of deoxyribonucleic acid by highperformance liquid chromatography. Int J Syst Bacteriol 39, 159-167.

Nielsen, P., Fritze, D. \& Priest, F. G. (1995). Phenetic diversity of alkaliphilic Bacillus strains: proposal for nine new species. Microbiology 141, 1745-1761.

Saitou, N. \& Nei, M. (1987). The neighbor-joining method: a new method for reconstructing phylogenetic trees. Mol Biol Evol 4, 406-425.

Schleifer, K. H. (1985). Analysis of the chemical composition and primary structure of murein. Methods Microbiol 18, 123-156.

Schleifer, K. H. \& Kandler, O. (1972). Peptidoglycan types of bacterial cell walls and their taxonomic implications. Bacteriol Rev 36, 407-477. 
Thompson, J. D., Gibson, T. J., Plewniak, F., Jeanmougin, F. \& Higgins, D. G. (1997). The CLUSTAL_X windows interface: flexible strategies for multiple sequence alignment aided by quality analysis tools. Nucleic Acids Res 25, 4876-4882.

Tiago, I., Chung, A. \& Verissimo, A. (2004). Bacterial diversity in a nonsaline alkaline environment: heterotrophic aerobic populations. Appl Environ Microbiol 70, 7378-7387.
Tiago, I., Pires, C., Mendes, V., Morais, P. V., da Costa, M. \& Verissimo, A. (2005). Microcella putealis gen. nov., sp. nov., a grampositive alkaliphilic bacterium isolated from a nonsaline alkaline groundwater. Syst Appl Microbiol 28, 479-487.

Tindall, B. J. (1989). Fully saturated menaquinones in the archaebacterium Pyrobaculum islandicum. FEMS Microbiol Lett 60, 251-254. 